\section{Gold(I) Complexes of}

1,2-bis(butylphenyl phosphino)ethane and cis-1,2-bis(butyl phenylphosphino) ethylene

\author{
David S. Khanye ${ }^{1}$, Judy Caddy ${ }^{1,2^{*}}$ and \\ Marcus Layh ${ }^{1}$ \\ 1 School of Chemistry, University of the \\ Witwatersrand, Private Bag 3, WITS, 2050, South \\ Africa. \\ 2 Project AuTEK, Mintek, Private Bag X3015, Randburg, \\ 2125, South Africa.
}

'To whom the correspondence should be addressed. E-mail: judyc@mintek.co.za

\begin{abstract}
The well established and known chemistry of metal phosphides as nucleophilic and reactive precursors has been used as a suitable synthetic approach in the synthesis of 1,2-bis(butylphenylphosphino) ethane (bppe) (5) and cis-1,2-bis(butylphenylphosphino)ethylene (bppey) (6). Adducts of bridged and bis-chelated gold(I) with 5 and 6 , as well as silver(I) with 5 , have been prepared in moderate to good yields. These complexes have been characterised by solution NMR spectroscopy, mass spectrometry (FAB) and microanalysis in case of 10a, $10 \mathrm{~b}$ and 11.
\end{abstract}

\section{Introduction}

Tertiary bis-phosphines of the form $R_{2} P-\left(C_{2}\right)_{n}-P R_{2}(n=1-4$ and $\mathrm{R}=\mathrm{Me}$, Et, $t-\mathrm{Bu}$ and $\mathrm{Ph})$ and cis- $\mathrm{R}_{2} \mathrm{PCH}=\mathrm{CHPR}_{2}(\mathrm{R}=\mathrm{Ph})$ are often used as chelating ligands for a wide range of transition metals.[1-4] These ligands have shown wider applications in metal complexation reactions and have attracted much attention, especially in the fields of medicine and catalysis.[59] They are versatile ligands in stabilising metal ions, especially transition metals in their lower oxidation states,[10] and have contributed to the fundamental understanding of the coordination chemistry of transition metals.[6] It is now well established that the strong $\pi$-acceptor ability of phosphines enables the stabilisation of even relatively electron-rich transition metals.[11]

Since the early application of 1,2-bis(diphenylphosphino) ethane (dppe) (1) and cis-1,2-bis(diphenylphosphino) ethylene (dppey) (2) (Figure 1) as chelating phosphine ligands, research efforts have more recently been centred on modifying the organic substituents on the phosphorus atom by the introduction of alkyl groups,[12] pyridyls,[13,14] or substituted aryls such as O-anisyl, 1-naphthyl, $\mathrm{C}-\mathrm{C}_{6} \mathrm{H}_{5},[15]$ in an effort to tailor the ligand to suit the specific application. The modification of bis-phosphines has been extended to the introduction of solubilising groups into the ethane bridge of dppe.[16] Thus, properties such as the electronic nature, the steric requirements or solubility of the ligand and their corresponding metal complexes can be fine-tuned to suit the desired application.

Gold(I) has been known to form numerous complexes with phosphine ligands, the majority of them being two-coordinate gold complexes. It was not until 1984, that ${ }^{31} \mathrm{P}$ NMR studies of the bridged di-gold diphosphine complex, [(AuCl) $\left.{ }_{2}(\mathrm{dppe})\right]$ (3), in presence of free dppe ligand demonstrated the formation of a four-coordinate complex, $\left[\mathrm{Au}(\mathrm{dppe})_{2}\right]^{+} \mathrm{Cl}^{-}$(4) (Figure 2).[17]

Silver, as the lighter congener of gold, shows an equally interesting coordination chemistry with phosphine ligands leading to a large variety of complexes of different nuclearity (mononuclear to polynuclear)[18] and bonding modes (bridging and chelating).[19]

Due to our ongoing research in the coordination chemistry of metal-phosphine complexes, we became interested in the coordination chemistry of ligands $\mathbf{5}$ and $\mathbf{6}$.[20,21] Thus, the research efforts presented herein compliment reports which describe the significant change in metal complex properties as a result of substitution on the phosphorus atom or the bridging carbon atom of dppe analogues.[16] Here, we report the synthesis of $\mathbf{5}$ and $\mathbf{6}$ (Figure 3), as modified analogues of $\mathbf{1}$ and $\mathbf{2}$, and their subsequent metal complexation with gold and silver (in case of $\mathbf{5}$ ). 


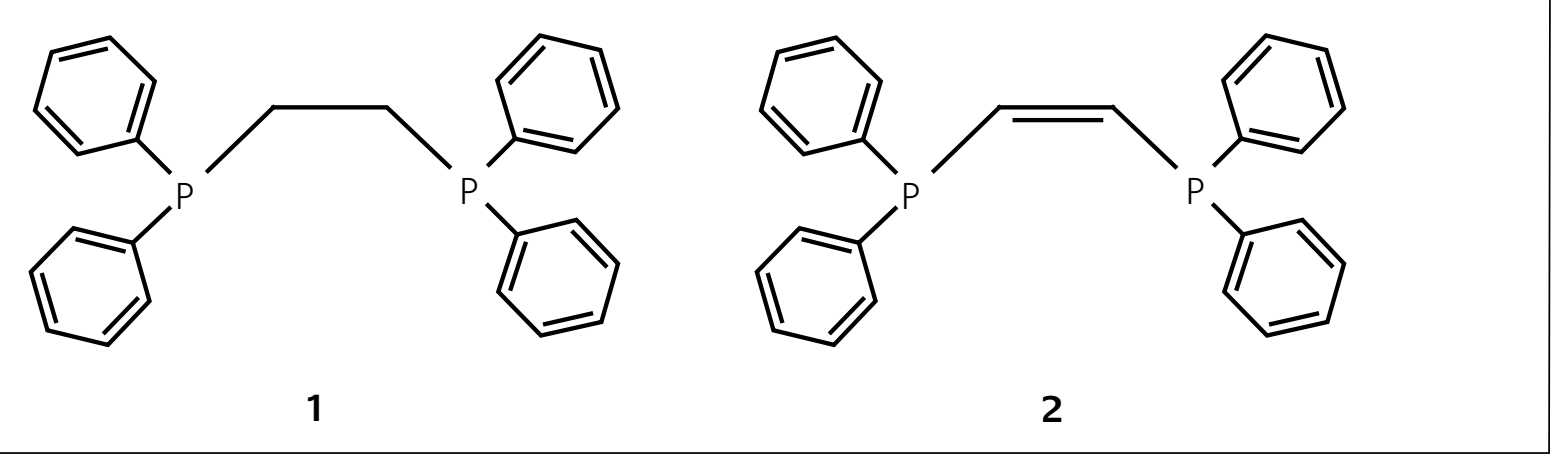

\section{Figure 1}

Bis-phosphine ligands, dppe and dppey.
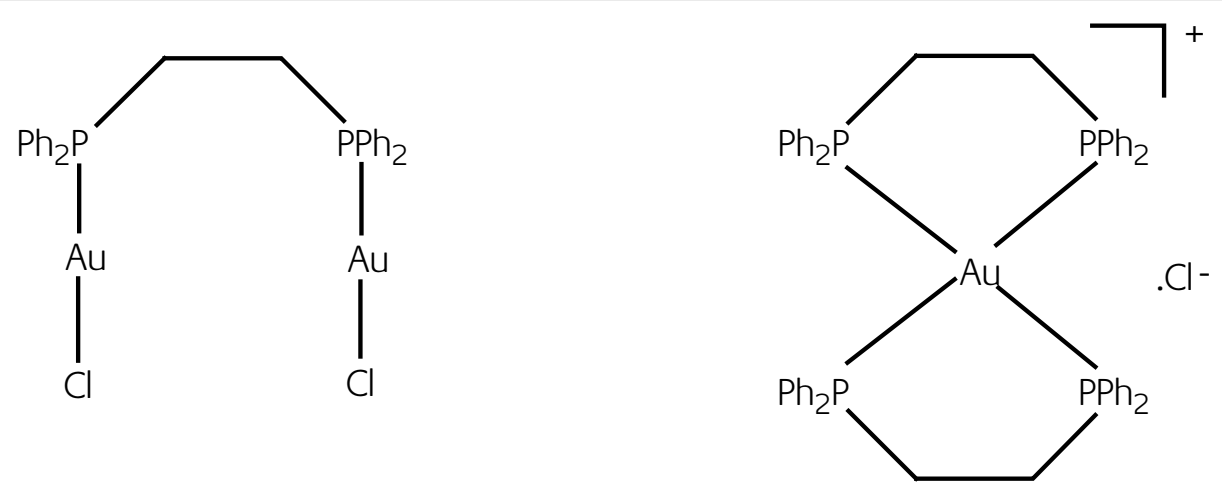

3

4

\section{Figure 2}

Bis- phosphine gold complexes, $\left[\mathrm{AuCl}_{2}(\mathrm{dppe})\right]$ and $\left[\mathrm{Au}(\mathrm{dppe})_{2}\right]^{+} \mathrm{Cl}$.
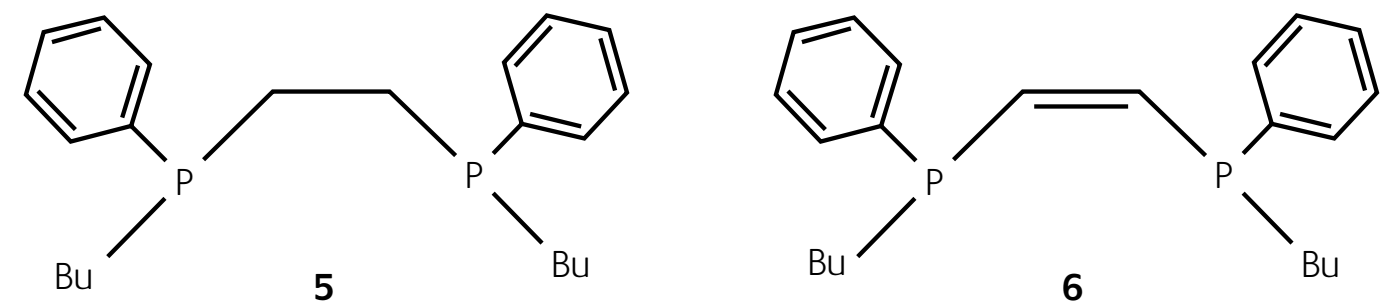

\section{Figure 3}

Modified bis-phosphine ligands with butyl groups, bppe and bppey.

\section{Experimental Section}

All manipulations were carried out under argon atmosphere, using standard Schlenk-techniques. Solvents were distilled from sodium/benzophenone ketyl or calcium hydride and degassed. Deuterated solvents were degassed by freezedrying and kept under argon and on molecular sieves. NMR spectra were recorded in $\mathrm{CDCl}_{3}$ or $\mathrm{d}_{6}$-DMSO at $298 \mathrm{~K}$ using the following Bruker instruments, AVANCE $300\left({ }^{1} \mathrm{H} 300.13 ;{ }^{31} \mathrm{P}\right.$ 121.5; ${ }^{13} \mathrm{C} 75.5 \mathrm{MHz}$ ) AVANCE DRX 400 ( ${ }^{1} \mathrm{H} 400.13 ;{ }^{31} \mathrm{P}$ 161.9; ${ }^{13} \mathrm{C} 100.6 \mathrm{MHz}$ ) and referenced internally to residual solvent resonances (data in $\delta$ ) in the case of ${ }^{1} \mathrm{H}$ and ${ }^{13} \mathrm{C}$ spectra, while the ${ }^{31} \mathrm{P}$ spectra were referenced externally to $85 \% \mathrm{H}_{3} \mathrm{PO}_{4}$. All NMR spectra other than ${ }^{1} \mathrm{H}$ NMR were proton-decoupled.
FAB-MS spectra were collected using a VG70-SEQ instrument in positive ion mode. Elemental analyses were determined on a Thermo Flash EA1112 CHNS-O elemental analyzer at the University of Cape Town. The following abbreviations are used throughout the experimental section: bs = broad singlet, $d$ = doublet, $d d=$ doublet of doublet, $m$ = multiplet, $s$ = singlet. Coupling constants, $\mathrm{J}$, are measured in Hertz $(\mathrm{Hz})$.

\section{Synthesis of butyldiphenylphosphine, $\mathrm{Ph}_{2} \mathrm{PBu}$}

$\mathrm{Ph}_{3} \mathrm{P}(26.4 \mathrm{~g}, 104.8 \mathrm{mmol})$ was dissolved in $100 \mathrm{~cm}^{3}$ of tetrahydrofuran (THF). The mixture was added dropwise at 
$0{ }^{\circ} \mathrm{C}$ to a suspension of granular lithium metal $(1.60 \mathrm{~g}, 230.5$ $\mathrm{mmol}$ ) in $100 \mathrm{~cm}^{3}$ of THF. The reaction was stirred at $0{ }^{\circ} \mathrm{C}$ for $1 \mathrm{hr}$. This was accompanied by a colour change from colourless to red-brown. The mixture was allowed to warm to room temperature and then stirred for 72 hrs. The unreacted lithium metal was removed by filtration. To the red-brown filtrate, $n$-butylchloride $\left(22.7 \mathrm{~cm}^{3}, 217.4 \mathrm{mmol}\right)$ in $20 \mathrm{~cm}^{3}$ hexane was added dropwise at $0{ }^{\circ} \mathrm{C}$, while rapidly stirring. The reaction mixture was stirred at room temperature overnight. After removing the volatiles in vacuo, $100 \mathrm{~cm}^{3}$ of dried hexane were added to the red-brown viscous oil to precipitate $\mathrm{LiCl}$ from the solution. The colourless solution was filtered by means of a cannula to remove LiCl. Hexane was removed from the filtrate in vacuo to give a yellow viscous oil, which became a colourless liquid after distillation under vacuum. Yield: $13.97 \mathrm{~g}, 64 \%$. Boiling point: $105-110{ }^{\circ} \mathrm{C} /$ $85.5 \times 10^{-4} \mathrm{mmHg}$ (lit. [22]. $100-102^{\circ} \mathrm{C} / 2.63 \times 10^{-4} \mathrm{mmHg}$ ). ${ }^{31} \mathrm{P}-\mathrm{NMR}\left(\mathrm{CDCl}_{3}\right): \delta-15.9 \mathrm{ppm}(\mathrm{s})$.

\section{Synthesis of $\mathrm{Ph}(\mathrm{Bu}) \mathrm{PCH}_{2} \mathrm{CH}_{2} \mathrm{P}(\mathrm{Bu}) \mathrm{Ph}$ (5)}

Method A: A solution of $\mathrm{Ph}_{2} \mathrm{BuP}(5 \mathrm{~g}, 20.6 \mathrm{mmol})$ in $25 \mathrm{~cm}^{3}$ THF was added dropwise to a suspension of granular lithium metal $(0.285 \mathrm{~g}, 41.2 \mathrm{mmol})$ in $60 \mathrm{~cm}^{3}$ of THF at $0{ }^{\circ} \mathrm{C}$. The reaction mixture was stirred at $0{ }^{\circ} \mathrm{C}$ for $1 \mathrm{hr}$. This was accompanied by a colour change from colourless to red-brown. The mixture was allowed to warm to room temperature and then stirred for 72 hrs. The unreacted lithium metal was removed by filtration. To the red-brown filtrate, 1,2-dichloroethane (1.02 g, $10.3 \mathrm{mmol})$ in $25 \mathrm{~cm}^{3}$ hexane was added dropwise at $0{ }^{\circ} \mathrm{C}$, while rapidly stirring. The reaction mixture was stirred at room temperature overnight. The white-yellow reaction mixture was extracted with hexane. The hexane was removed in vacuo to give a yellow oil $(0.5 \mathrm{~g}, 17 \%)$. Method B: 1,2-Bis(diphenylphos phino)ethane (dppe) (10.0 g, $25.1 \mathrm{mmol}$ ) was dissolved in $100 \mathrm{~cm}^{3}$ of THF. Further, the mixture was added dropwise to a suspension of granular lithium metal $(0.784 \mathrm{~g}, 112.9$ $\mathrm{mmol}$ ) in $120 \mathrm{~cm}^{3}$ at $0{ }^{\circ} \mathrm{C}$. The reaction was stirred at $0{ }^{\circ} \mathrm{C}$ for $1 \mathrm{hr}$. This was accompanied by a colour change from colourless to red-brown. The mixture was allowed to warm to room temperature and then stirred for 72 hrs. The unreacted lithium metal was removed by filtration. To the red-brown filtrate, $n$-butylchloride $\left(12.3 \mathrm{~cm}^{3}\right.$, $112.9 \mathrm{mmol}$ ) in $20 \mathrm{~cm}^{3}$ of hexane was added dropwise at $-30{ }^{\circ} \mathrm{C}$, while rapidly stirring. The reaction mixture was stirred at room temperature overnight. After removing the solvent in vacuo, a further $100 \mathrm{~cm}^{3}$ of hexane were added to the red-brown viscous oil to precipitate $\mathrm{LiCl}$ from the oil. The hexane was removed in vacuo to give a yellow viscous oil, that after vacuum distillation yielded a colourless oil. Yield: $4.85 \mathrm{~g}, 54 \%$ (Mixture of diastereomers). Boiling point: $170-175{ }^{\circ} \mathrm{C} / 140 \mathrm{mmHg} .{ }^{1} \mathrm{H}-\mathrm{NMR}\left(\mathrm{CDCl}_{3}\right): \delta 0.79\left[\mathrm{t}, \mathrm{CH}_{3}\right.$, $6 \mathrm{H},{ }^{3} J_{H-H}=6.9 \mathrm{~Hz}$ ], 1.27 [unresolved $\mathrm{t}, \mathrm{CH}_{2}, 8 \mathrm{H}$ ], $1.56-1.61$ $\left[\mathrm{m}, \mathrm{CH}_{2}, 8 \mathrm{H}\right], 7.34-7.37$ [m, 2Ph, 10H]. ${ }^{31} \mathrm{P}-\mathrm{NMR}\left(\mathrm{CDCl}_{3}\right): \delta$
-19.6, -19.9. ${ }^{13} \mathrm{C}-\mathrm{NMR}\left(\mathrm{CDCl}_{3}\right): \delta 13.7\left[\mathrm{~s}, \mathrm{CH}_{3}\right], 24.1-24.3$ [pseudo triplet, $\mathrm{CH}_{2}$ ], $27.2-28.0$ [m, $\mathrm{CH}_{2}$ ], 128.2 [m, p-Ph], $128.6[\mathrm{~d}, \mathrm{o} / \mathrm{m}-\mathrm{Ph}, \mathrm{J}=3.3 \mathrm{~Hz}], 132.1-132.4$ [m, o/m-Ph], 137.9 - 138.0 [m, ipso-Ph]. Mass spectrum (EI): $\mathrm{m} / \mathrm{z}=358.2$ $(10 \%)[\mathrm{M}]^{+}, 301.3(18 \%)[\mathrm{M}-\mathrm{Bu}]^{+}$.

\section{Synthesis of $c i s-\mathrm{Ph}(\mathrm{Bu}) \mathrm{PCH}=\mathrm{CHP}(\mathrm{Bu}) \mathrm{Ph}(6)$}

$\mathrm{Ph}_{2} \mathrm{PCH}=\mathrm{CHPPh}_{2}(3.0 \mathrm{~g}, 7.57 \mathrm{mmol})$ was dissolved in 100 $\mathrm{cm}^{3}$ of THF. Further, the mixture was added dropwise to a suspension of granular lithium metal (0.236 g, 34.0 $\mathrm{mmol}$ ) in $100 \mathrm{~cm}^{3}$ of THF at $0^{\circ} \mathrm{C}$. The reaction mixture was stirred at $0^{\circ} \mathrm{C}$ for $1 \mathrm{hr}$. This was accompanied by a colour change from colourless to red-brown. The mixture was allowed to warm to room temperature and then stirred for 24 hrs. The unreacted lithium metal was removed by filtration. To the red-brown filtrate, $n$-butylchloride $\left(4 \mathrm{~cm}^{3}, 34.1 \mathrm{mmol}\right)$ in $30 \mathrm{~cm}^{3}$ hexane was added dropwise at $0{ }^{\circ} \mathrm{C}$, while rapidly stirring. The reaction mixture was stirred at room temperature overnight. The solvent was removed in vacuo to give a red-brown oil. Dry hexane $\left(2 \times 100 \mathrm{~cm}^{3}\right)$ was added and a yellow-white precipitate formed, which was separated by filtration. The solvent was removed in vacuo off the filtrate and the obtained viscous oil was vacuum distilled to give a yellow oil. Yield: 2.09 g, 78 \%. Boiling Point: $110-115{ }^{\circ} \mathrm{C} / 131.6 \mathrm{mmHg}$. ${ }^{1} \mathrm{H}$ NMR (DMSO): $\delta 0.86\left[\mathrm{t}, \mathrm{CH}_{3}, 3 \mathrm{H},{ }^{3}{ }_{\mathrm{H}-\mathrm{H}}=6.8 \mathrm{~Hz}\right], 1.28$ - $1.40\left[\mathrm{~m}, \mathrm{CH}_{2}, 4 \mathrm{H}\right.$ ], 2.06 [pseudo t, $\mathrm{CH}_{2}, 2 \mathrm{H}, J=7.2 \mathrm{~Hz}$ ], $7.30-7.40[\mathrm{~m}, \mathrm{Ph}, \mathrm{CH}=\mathrm{CH}, 6 \mathrm{H}] .{ }^{31} \mathrm{P}$ NMR (DMSO): $\delta-16.7$ ppm. ${ }^{13} \mathrm{C}$ NMR (DMSO): $\delta 13.5\left[\mathrm{~s}, \mathrm{CH}_{3}\right], 23.4\left[\mathrm{~d}, \mathrm{CH}_{2}, J_{C-P}\right.$ $=13.1 \mathrm{~Hz}$ ], $26.4\left[\mathrm{~d}, \mathrm{CH}_{2}, J_{C-P}=11.1 \mathrm{~Hz}\right], 27.6\left[\mathrm{~d}, \mathrm{CH}_{2}, J_{C-P}=\right.$ $15.8 \mathrm{~Hz}$ ], 128.3 [s, p-Ph], 128.4 [s, m/o-Ph], 132.1 [s, o/m$\mathrm{Ph}] 132.3[\mathrm{~s}, \mathrm{CH}=\mathrm{CH}], 138.5\left[\mathrm{~d}\right.$, ipso-Ph, $\left.{ }^{1}{ }_{C-P}=14.1 \mathrm{~Hz}\right]$. Mass spectrum (EI): $m / z=356.2(10 \%)\left[\mathrm{M}^{+}\right], 243.2(100$ \%) $[\mathrm{M}-2 \mathrm{Bu}]^{+}$.

\section{Synthesis of $\left[(\mathrm{AuCl})_{2} \mathrm{Ph}(\mathrm{Bu}) \mathrm{PCH}_{2} \mathrm{CH}_{2} \mathrm{P}(\mathrm{Bu})\right.$ $\mathrm{Ph}$ (8a)}

[AuCl(SMe 2$)](0.17 \mathrm{~g}, 0.56 \mathrm{mmol})$ was dissolved in $10 \mathrm{~cm}^{3}$ of $\mathrm{CH}_{2} \mathrm{Cl}_{2}$. Further, a solution of $\mathrm{Ph}(\mathrm{Bu}) \mathrm{PCH}_{2} \mathrm{CH}_{2} \mathrm{P}(\mathrm{Bu}) \mathrm{Ph}$ ( $0.10 \mathrm{~g}, 0.28 \mathrm{mmol})$ in $5 \mathrm{~cm}^{3}$ of $\mathrm{CH}_{2} \mathrm{Cl}_{2}$ was slowly added to the reaction mixture at room temperature. After the mixture was stirred for 2 hrs at room temperature, the colourless solution was filtered by means of a cannula and the solvent removed in vacuo to give a white solid. Yield: $0.17 \mathrm{~g}, 74 \% .{ }^{1} \mathrm{H}$ NMR $\left(\mathrm{CDCl}_{3}\right): \delta 0.81-0.92\left[\mathrm{~m}, 2 \mathrm{CH}_{3}, 6 \mathrm{H}\right]$, $1.35-1.42\left[\mathrm{~m}, \mathrm{CH}_{2}, 8 \mathrm{H}\right], 2.07-2.10\left[\mathrm{~m}, \mathrm{CH}_{2}, 4 \mathrm{H}\right], 2.40$ - $2.44\left[\mathrm{~m}, \mathrm{CH}_{2}, 2 \mathrm{H}\right], 7.46-7.63$ [m, Ph, 10H]. ${ }^{31} \mathrm{P}-\mathrm{NMR}$ $\left(\mathrm{CDCl}_{3}\right): \delta 33.2,32.4$. Mass spectrum (FAB): $m / z=786.7$

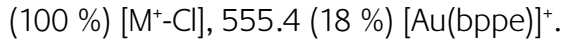




\section{Synthesis of $\left[(\mathrm{AuCl})_{2} \mathrm{Ph}(\mathrm{Bu}) \mathrm{PHC}=\mathrm{CHP}(\mathrm{Bu})\right.$ $\mathrm{Ph}](9)$}

[AuCl(SMe $\left.\left.)_{2}\right)\right](0.17 \mathrm{~g}, 0.56 \mathrm{mmol})$ was dissolved in $10 \mathrm{~cm}^{3}$ of $\mathrm{CH}_{2} \mathrm{Cl}_{2}$. Further, a solution of $\mathrm{Ph}(\mathrm{Bu}) \mathrm{PCH}=\mathrm{CHP}(\mathrm{Bu}) \mathrm{Ph}(0.10$ $\mathrm{g}, 0.28 \mathrm{mmol}$ ) in $5 \mathrm{~cm}^{3}$ of $\mathrm{CH}_{2} \mathrm{Cl}_{2}$ was slowly added to the reaction mixture at room temperature. After the mixture was stirred for 3 hrs at room temperature, the brown solution was filtered by means of a cannula and the solvent removed in vacuo to give a brown solid. Yield: $0.18 \mathrm{~g}, 78 \%$. ${ }^{1} \mathrm{H}$ NMR (DMSO): $\delta 0.69\left[\mathrm{t}, \mathrm{CH}_{3}, 3 \mathrm{H},{ }^{3} \mathrm{H}_{\mathrm{H}-\mathrm{H}}=6.7 \mathrm{~Hz}\right], 1.24\left[\mathrm{~s}, \mathrm{CH}_{2}, 4 \mathrm{H}\right]$, $2.44\left[\mathrm{~m}, \mathrm{CH}_{2}, 2 \mathrm{H}\right], 7.40-7.60$ [m, Ph / HC=CH, 6H]. ${ }^{31} \mathrm{P}-\mathrm{NMR}$ (DMSO): $\delta$ 31.5. Mass spectrum (FAB): $m / z=785.2$ (0.5\%) $\left[\mathrm{M}^{+}-\mathrm{Cl}\right], 439.2(25 \%)[\mathrm{Au}(\mathrm{PhPCH}=\mathrm{CHPPh})]^{+}$.

\section{Synthesis of $\left[\mathrm{Au}\left(\mathrm{Ph}(\mathrm{Bu}) \mathrm{PCH}_{2} \mathrm{CH}_{2} \mathrm{P}(\mathrm{Bu}) \mathrm{Ph}\right)_{2}\right]$ $\mathrm{Cl}$ (10a)}

[AuCl(SMe $)](0.49 \mathrm{~g}, 1.68 \mathrm{mmol})$ was dissolved in $10 \mathrm{~cm}^{3}$ of $\mathrm{CH}_{2} \mathrm{Cl}_{2}$. Further, a solution of $\mathrm{Ph}(\mathrm{Bu}) \mathrm{PCH}_{2} \mathrm{CH}_{2} \mathrm{P}(\mathrm{Bu}) \mathrm{Ph}(1.20 \mathrm{~g}$, $3.35 \mathrm{mmol}$ ) in $10 \mathrm{~cm}^{3}$ of $\mathrm{CH}_{2} \mathrm{Cl}_{2}$ was added dropwise to the reaction mixture at room temperature. The reaction mixture was stirred overnight at room temperature. The colourless solution was filtered by means of a cannula and the solvent removed in vacuo to give a white solid. Yield: $1.35 \mathrm{~g}, 85 \%$. Calc. for $\mathrm{C}_{44} \mathrm{H}_{64} \mathrm{AuP}_{4} \mathrm{Cl}$ : C, 55.7; $\mathrm{H}, 6.79 \%$. Found: C, 53.7; $\mathrm{H}$, $6.77 \% .{ }^{1} \mathrm{H}$ NMR $\left(\mathrm{CDCl}_{3}\right): \delta 0.70-0.86\left[\mathrm{~m}, \mathrm{CH}_{3}, 12 \mathrm{H}\right], 0.91$ - $1.45\left[\mathrm{~m}, \mathrm{CH}_{2}, 16 \mathrm{H}\right], 1.91-2.15\left[\mathrm{~m}, \mathrm{CH}_{2}, 16 \mathrm{H}\right], 7.27-7.65$ $[\mathrm{m}, \mathrm{Ph}, 2 \mathrm{OH}] .{ }^{31} \mathrm{P}-\mathrm{NMR}\left(\mathrm{CDCl}_{3}\right): \delta 15.1$ and 15.5 (Isomeric mixture). ${ }^{13} \mathrm{C}-\mathrm{NMR}\left(\mathrm{CDCl}_{3}\right): \delta 13.3\left[\mathrm{~s}, \mathrm{CH}_{3}\right], 23.6\left[\mathrm{~s}, \mathrm{CH}_{2}\right], 24.0$ [s, $\left.\mathrm{CH}_{2}\right], 27.4\left[\mathrm{~m}, \mathrm{CH}_{2}\right], 29.0\left[\mathrm{~m}, \mathrm{CH}_{2}\right], 128.8\left[\mathrm{~d}, \mathrm{Ph}, \mathrm{J}_{C \cdot \mathrm{p}}=9.8\right.$ $\mathrm{Hz}$ ], 129.1 [br s, Ph], 130.4 [s, Ph], 133.0 [d, ipso-Ph, ' ${ }^{1} \mathrm{C}_{-\mathrm{p}}=$ $13.9 \mathrm{~Hz}$. Mass spectrum (FAB): $m / z=913.2(100 \%)\left[\mathrm{M}^{+}-\mathrm{Cl}\right]$, $555.2(22 \%)\left[\mathrm{Au}(\mathrm{bppe})^{+}\right]$.

\section{Synthesis of $\left[\mathrm{Au}(\mathrm{Ph}(\mathrm{Bu}) \mathrm{PHC}=\mathrm{CHP}(\mathrm{Bu}) \mathrm{Ph})_{2}\right]$ $\mathrm{Cl}(11)$}

[AuCl(SMe $)](0.44 \mathrm{~g}, 1.49 \mathrm{mmol})$ was dissolved in $15 \mathrm{~cm}^{3}$ of $\mathrm{CH}_{2} \mathrm{Cl}_{2}$. Further, a solution of $\mathrm{Ph}(\mathrm{Bu}) \mathrm{PHC}=\mathrm{CHP}(\mathrm{Bu}) \mathrm{Ph}(1.09 \mathrm{~g}$, $2.97 \mathrm{mmol}$ ) in $20 \mathrm{~cm}^{3}$ of $\mathrm{CH}_{2} \mathrm{Cl}_{2}$ was added dropwise to the reaction mixture at room temperature. The reaction mixture was stirred overnight at room temperature. The brown solution was filtered by means of a cannula and the solvent removed in vacuo to give a brown solid. The solid was washed with a mixture of $\mathrm{CH}_{2} \mathrm{Cl}_{2} /$ hexane and then dried in vacuo. Yield: $1.31 \mathrm{~g}$, $93 \%$. Calc. for $\mathrm{C}_{44} \mathrm{H}_{60} \mathrm{AuP}_{4} \mathrm{Cl}$ : C, 55.9; H, $6.4 \%$. Found: C, 53.2; $\mathrm{H}, 5.97 \%$. ${ }^{1} \mathrm{H}$ NMR (DMSO): $\delta 0.73\left[\mathrm{~m}, \mathrm{CH}_{3}, 12 \mathrm{H}\right], 1.28$ [m, $\left.\mathrm{CH}_{2}, 18 \mathrm{H}\right], 2.36\left[\mathrm{~m}, \mathrm{CH}_{2}, 6 \mathrm{H}\right], 7.40-7.51[\mathrm{~m}, \mathrm{Ph}, \mathrm{CH}=\mathrm{CH}$, 24H]. ${ }^{31} \mathrm{P}-\mathrm{NMR}$ (DMSO): $\delta 22.3 .{ }^{13} \mathrm{C}-\mathrm{NMR}$ (DMSO): $\delta 13.7$ [s, $\left.\mathrm{CH}_{3}\right], 20.4$, [s, $\left.\mathrm{CH}_{2}\right], 24.5\left[\mathrm{~m}, \mathrm{CH}_{2}\right], 28.0\left[\mathrm{~m}, \mathrm{CH}_{2}\right], 129.3$ [s, p$\mathrm{Ph}], 131.9$ [m, o/m-Ph], 132.3 [m, o/m-Ph], 133.9 [s, - $\mathrm{CH}=\mathrm{CH}-]$, 135.5 [m, ipso-Ph]. Mass spectrum (FAB): $m / z=909.3$ (1.5\%) $\left[\mathrm{M}^{+}-\mathrm{Cl}\right], 795.2(6.0 \%)\left[\mathrm{M}^{+}-2 \mathrm{Bu}\right], 681.3(100 \%)\left[\mathrm{M}^{+}-4 \mathrm{Bu}\right]$.

\section{Synthesis of $\left[\left(\mathrm{AgNO}_{3}\right)_{2}\left(\mathrm{Ph}(\mathrm{Bu}) \mathrm{PCH}_{2} \mathrm{CH}_{2} \mathrm{P}\right.\right.$ (Bu)Ph)] (8b)}

$\mathrm{AgNO}_{3}(0.096 \mathrm{~g}, 0.57 \mathrm{mmol})$ was suspended in $15 \mathrm{~cm}^{3}$ of $\mathrm{CH}_{2} \mathrm{Cl}_{2}$. Further, a solution of $\mathrm{Ph}(\mathrm{Bu}) \mathrm{PCH}_{2} \mathrm{CH}_{2} \mathrm{P}(\mathrm{Bu}) \mathrm{Ph}(0.10$ $\mathrm{g}, 0.28 \mathrm{mmol}$ ) in $10 \mathrm{~cm}^{3}$ of $\mathrm{CH}_{2} \mathrm{Cl}_{2}$ was slowly added to the reaction mixture at room temperature. After the mixture was stirred for 90 mins at room temperature, the colourised solution was filtered by means of a cannula and the solvent removed to give a brown solid. Yield: $0.1 \mathrm{~g}, 51 \%$. ${ }^{1} \mathrm{H}$ NMR $\left(\mathrm{CDCl}_{3}\right): \delta 0.71-0.87\left[\mathrm{~m}, \mathrm{CH}_{3}, 6 \mathrm{H}\right], 1.22-1.29\left[\mathrm{~m}, \mathrm{CH}_{2}, 8 \mathrm{H}\right]$, $1.87-2.24\left[\mathrm{~m}, \mathrm{CH}_{2}, 8 \mathrm{H}\right], 7.31-7.60[\mathrm{~m}, \mathrm{Ph}, 1 \mathrm{OH}] .{ }^{31} \mathrm{P}-\mathrm{NMR}$ $\left(\mathrm{CDCl}_{3}\right): \delta 9.5 .\left[\mathrm{d}, J_{A q-P}=225 \mathrm{~Hz}\right]{ }^{13} \mathrm{C}-\mathrm{NMR}\left(\mathrm{CDCl}_{3}\right): \delta 13.50[\mathrm{~s}$, $\left.\mathrm{CH}_{3}\right], 13.52\left[\mathrm{~s}, \mathrm{CH}_{3}\right], 23.8\left[\mathrm{~s}, \mathrm{CH}_{2}\right], 24.0\left[\mathrm{~s}, \mathrm{CH}_{2}\right], 27.7\left[\mathrm{~s}, \mathrm{CH}_{2}\right]$, 125.5 - $133.5(\mathrm{~m}, \mathrm{Ph})$. Mass spectrum (FAB): $m / z=636.2$ (6.8\%) $\left[\mathrm{Ag}_{2}(\mathrm{bppe}) \mathrm{NO}_{3}\right]^{+}, 466.3$ (61\%) $[\mathrm{Ag}(\mathrm{bppe})]^{+}$.

\section{Synthesis of $\left[\mathrm{Ag}\left(\mathrm{Ph}(\mathrm{Bu}) \mathrm{P}\left(\mathrm{CH}_{2} \mathrm{CH}_{2} \mathrm{P}(\mathrm{Bu}) \mathrm{Ph}\right)_{2}\right]\right.$ $\mathrm{ClO}_{4}(10 \mathrm{~b})$}

$\mathrm{AgClO}_{4}(0.36 \mathrm{~g}, 1.68 \mathrm{mmol})$ was suspended in $10 \mathrm{~cm}^{3}$ of $\mathrm{CH}_{2} \mathrm{Cl}_{2}$. Further, a solution of $\mathrm{Ph}(\mathrm{Bu}) \mathrm{PCH}_{2} \mathrm{CH}_{2} \mathrm{P}(\mathrm{Bu}) \mathrm{Ph}(1.20 \mathrm{~g}$, $3.35 \mathrm{mmol}$ ) in $10 \mathrm{~cm}^{3}$ of $\mathrm{CH}_{2} \mathrm{Cl}_{2}$ was added dropwise to the reaction mixture at room temperature. The reaction mixture was stirred overnight at room temperature. The colourless solution was filtered by means of a cannula and the solvent removed in vacuo to give a white solid. Yield: $1.40 \mathrm{~g}, 91 \%$. Calc. for $\mathrm{C}_{44} \mathrm{H}_{64} \mathrm{AgClO}_{4}$ : C, 57.2; $\mathrm{H}, 7.0 \%$. Found: $\mathrm{C}, 55.8 ; \mathrm{H}$, $6.82 \% .{ }^{1} \mathrm{H} \mathrm{NMR}\left(\mathrm{CDCl}_{3}\right): \delta 0.72-0.88\left[\mathrm{~m}, \mathrm{CH}_{3}, 3 \mathrm{H}\right], 1.29-1.4$ [m, $\left.\mathrm{CH}_{2}, 4 \mathrm{H}\right], 1.9-2.3$ [m, $\mathrm{CH}_{2}, 4 \mathrm{H}$ ], $7.34-7.50$ [m, Ph, 5H]. ${ }^{31} \mathrm{P}-\mathrm{NMR}\left(\mathrm{CDCl}_{3}\right): \delta-2.1\left[\mathrm{~d}, J_{\text {Ag-P }}=240 \mathrm{~Hz}\right] .{ }^{13} \mathrm{C}-\mathrm{NMR}\left(\mathrm{CDCl}_{3}\right): \delta$ $13.6\left[\mathrm{~s}, \mathrm{CH}_{3}\right], 24.1\left[\mathrm{~s}, \mathrm{br}, \mathrm{CH}_{2}\right], 27.8$ [s, br, $\left.\mathrm{CH}_{2}\right], 128.9-132.7$ (Ph). Mass spectrum (FAB): $m / z=823.5(31 \%)\left[\mathrm{M}^{+}-\mathrm{ClO}_{4}^{-}\right]$, 465.2(100\%) [Ag(bppe) $]^{+}$.

\section{Results and Discussion}

Various synthetic routes exist for the preparation of bisphosphine ligands. These include reaction methods such as reductive metallation of halophosphines, metal-halogen exchange, the metallation of primary and secondary phosphines with a strong base such as $n$-BuLi and the cleavage of $\mathrm{P}-\mathrm{C}$ bonds in tertiary phosphines with an alkali metal.[17] In this work the latter principle of P-C bond cleavage, [23-27], has been employed towards the synthesis of novel bppe (5) and bppey (6).

The reaction schemes towards the synthesis of the ligands and metal complexes are summarised in Scheme 1. The first method involved the synthesis of $n$-butyldiphenylphosphine from triphenylphosphine $\left(\mathrm{PPh}_{3}\right)(\mathbf{7})$, and thereafter the desired ligand via a lithium butylphenylphosphide intermediate. The second method involved the synthesis of bppe directly from bis-phosphine, dppe (1) (Figure 1).

The synthesis of the bis-phosphine, bppe (5), via P-C bond 


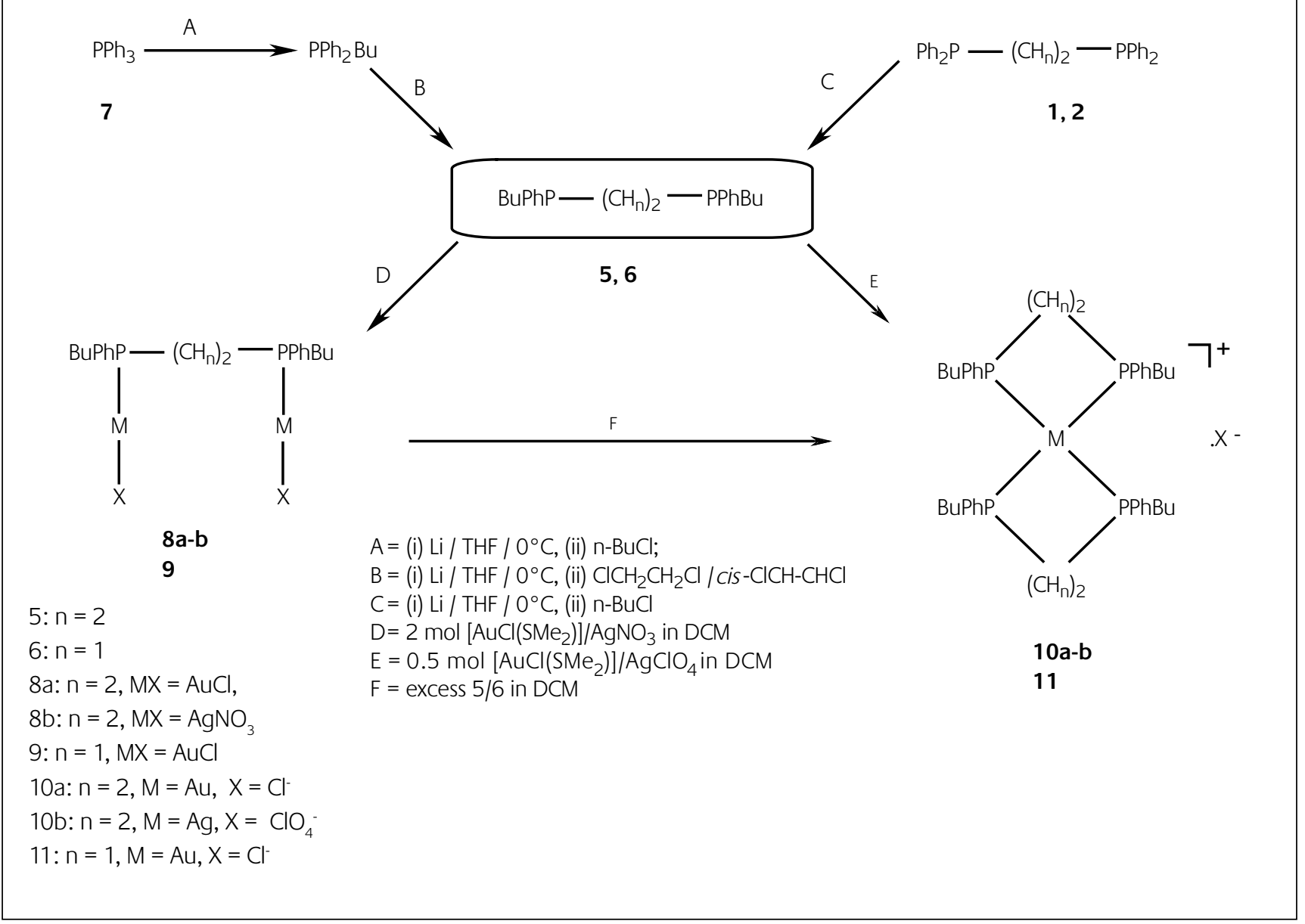

\section{Scheme 1}

Synthesis of cationic and neutral bis-phosphine group 11 metal complexes.

cleavage with an alkali metal involved the cleavage of $\mathrm{PPh}_{3}(\mathbf{7})$ by lithium metal in tetrahydrofuran, which results in a source of lithium diphenylphosphide ( LiPPh $_{2}$ ), a useful precursor for the preparation of bis-phosphine ligands. The reaction of $\mathrm{PPh}_{3}$ and lithium metal (step A) via lithium diphenylphosphide intermediate was accompanied by a red-brown colour, characteristic of the formation of the metal-phosphide.[27] Treatment of the red-brown solution with a solution of n-butylchloride readily afforded the butyldiphenylphosphine precursor $\left(\mathrm{Ph}_{2} \mathrm{PBu}\right)$ in moderate yield (64\%).

When $\mathrm{Ph}_{2} \mathrm{PBu}$ was subjected to similar reaction conditions the corresponding lithium butylphenylphosphide (LiPBuPh) intermediate (step B) was readily formed. In situ preparation of $\mathbf{5}$ by treating the LiPBuPh intermediate with 1,2-dichloroethane (step B) at low temperature yielded $\mathbf{5}$ in low yield $(17-40 \%)$. Although, the stereospecific reaction of $\mathrm{LiPPh}_{2}$ with either cis-1,2-dichloroethylene or trans-1,2dichloroethylene to successfully yield the corresponding phosphines, cis- $\mathrm{Ph}_{2} \mathrm{PCH}=\mathrm{CHPPh}_{2}$ or trans- $\mathrm{Ph}_{2} \mathrm{PCH}=\mathrm{CHPPh}_{2}$ has been reported previously,[28] treating LiPBuPh with cis-1,2dichloroethylene (step B) to form $\mathbf{6}$ resulted in a mixture of unidentifiable products.

Although many bis-phosphine ligands are being synthesised from $\mathrm{PPh}_{3}$, an attractive alternative approach, consisting of fewer synthetic steps, is the cleavage of the P-C bonds of the $\mathrm{Ph}_{2} \mathrm{P}\left(\mathrm{CH}_{n}\right)_{x} \mathrm{PPh}_{2}$ ligands, where $\mathrm{n}=2, \mathrm{x}=2$ (1) or $n=1, x=2(2)$, by an alkali metal.[2,12,24-27] The reaction of $\mathrm{Ph}_{2} \mathrm{P}\left(\mathrm{CH}_{\mathrm{n}}\right)_{\mathrm{x}} \mathrm{PPh}_{2}$ (1 or $\mathbf{2}$ ) with at least $4 \mathrm{~mol}$ equivalents of lithium metal to $1 \mathrm{~mol}$ phosphine resulted in the formation of the characteristic red-brown lithium diphosphide intermediate, $\mathrm{Li}(\mathrm{Ph}) \mathrm{P}\left(\mathrm{CH}_{\mathrm{n}}\right)_{x} \mathrm{P}(\mathrm{Ph}) \mathrm{Li}$ (step C). Further reaction of $\mathrm{Li}(\mathrm{Ph}) \mathrm{P}\left(\mathrm{CH}_{n}\right)_{x} \mathrm{P}(\mathrm{Ph}) \mathrm{Li}$ with 4.5 equivalents of $n$-butylchloride (step C) resulted in the formation of both ligands, $\mathbf{5}$ as mixture of isomers in moderate (54\%) and 6 in good yield (78\%). Both were characterised by both NMR spectroscopy and mass spectrometry.

The bis-phosphines 5 and $\mathbf{6}$ on complexation to gold(I), yielded the two and four co-ordinated gold(I) complexes $\mathbf{8 a}$, 9 and 10a, 11 (Scheme 1). The bridged digold(I) complexes, $\mathbf{8 a}$ and $\mathbf{9}$, were synthesised by a procedure similar to the one described in the literature for [(AuCl) $)_{2} \mathrm{dppe],[1]} \mathrm{which}$ involved the addition of half an equivalent of the appropriate ligand, $\mathbf{5}$ or $\mathbf{6}$ (step D), to a solution of $\left[\mathrm{AuCl}\left(\mathrm{SMe}_{2}\right)\right]$ at room temperature, resulting in the formation of $\mathbf{8 a}(57 \%)$ and $9(78 \%)$ as white and light brown solids, respectively. The four co-ordinated bis-chelated complexes $\mathbf{1 0 a}$ and $\mathbf{1 1}$ were synthesised via the established procedure of a 2:1 mol ratio of (P-P):Au(I).[1, 16,17,29] Thus, the reaction of two equivalents of $\mathbf{5}$ or $\mathbf{6}$ with a solution of $\left[\mathrm{AuCl}\left(\mathrm{SMe}_{2}\right)\right]$ in DCM (step E), readily afforded complexes $\mathbf{1 0 a}$ and $\mathbf{1 1}$ in good yields (85\% 
Table 1: ${ }^{31} P\left\{{ }^{1} H\right\}$ chemical shift resonances of the bridged and bis-chelated gold(I) and silver(I) complexes.

\begin{tabular}{|c|c|c|c|c|c|}
\hline \multicolumn{6}{|c|}{${ }^{31}$ P NMR } \\
\hline Ligand Type & P-P & {$\left[(\mathrm{MX})_{2}(\mathrm{P}-\mathrm{P})\right]$} & {$\left[\left(\mathrm{M}(\mathrm{P}-\mathrm{P})_{2}\right] \mathrm{X}\right.$} & Solvent & Metal \\
\hline \multirow[t]{2}{*}{ bppe* $^{*}$} & $-19.6 ;-19.9$ & $32.4,33.2$ & $15.1,15.5$ & $\mathrm{CDCl}_{3}$ & $\mathrm{Au}$ \\
\hline & & 9.5 & -2.1 & $\mathrm{CDCl}_{3}$ & $\mathrm{Ag}$ \\
\hline \multirow[t]{2}{*}{ dppe } & -11.9 & 31.5 & 20.8 & $\mathrm{CDCl}_{3}$ & $\mathrm{Au}$ \\
\hline & & 3.3 & 4.4 & $\mathrm{CDCl}_{3}$ & $\mathrm{Ag}$ \\
\hline bppey* & -16.7 & 31.5 & 22.3 & DMSO & $\mathrm{Au}$ \\
\hline dppey & -23.5 & 12.5 & 22.4 & $\mathrm{CDCl}_{3}$ & $\mathrm{Au}$ \\
\hline
\end{tabular}

*This work

and $93 \%$, respectively).

The complexation of $\mathbf{5}$ with stoichiometric amounts of silver salts $\left[\mathrm{AgNO}_{3}\right.$ (step D) and $\mathrm{AgClO}_{4}$ (step E)], via a similar procedure described for the gold complexes, yielded both the bridged di-silver $(\mathbf{8 b})$ and bis-chelated silver (10b) complex in moderate and good yields ( $51 \%$ and $91 \%$, respectively).

Complimentary to the one step preparation of the bis-chelated complexes, $\mathbf{1 0} \mathbf{a}-\mathbf{b}$ and $\mathbf{1 1}$, a two step approach could be undertaken, incorporating the bridged analogues (8a-b and 9) as intermediates. (Scheme 1, step F).

The corresponding gold and silver complexes (Scheme 1) were fully characterised by multinuclear NMR spectroscopy, elemental analysis (except $\mathbf{8 b}$ and $\mathbf{9}$ ) and mass spectrometry. The ${ }^{1} \mathrm{H}$ NMR spectra of the complex $\mathbf{8 a}, \mathbf{9}, \mathbf{8 b}, \mathbf{1 0 a}, \mathbf{1 0 b}$ and 11 showed a deshielding of the ethylenic protons on complexation compared to that of the free ligand. The deshielding of the ethylenic protons has been observed for various other complexes in the literature, such as $\left[(\mathrm{AuCl})_{2}\right.$ (dnpype)],[28] where $\mathrm{n}=2$ - 4, and dnpype = 1,2-bis(di-n-pyridylphosphino)ethane, [Au(dppe) $\left.)_{2}\right] \mathrm{Cl},[1,16]\left[\mathrm{Ag}(\mathrm{dppe})_{2}\right] \mathrm{NO}_{3},[30] \mathrm{Ag}$ (dnpype) $\left.)_{2}\right] \mathrm{NO}_{3},[31]$ and $\left[\mathrm{Cu}(\mathrm{dppe})_{2}\right] \mathrm{BF}_{4}$.[32] Furthermore, the ethylenic protons of the bridged di-gold(I) complexes, $\mathbf{8 a}$ and $\mathbf{9}$, are more deshielded than those of the bis-chelated complexes $\mathbf{1 0 a}$ and $\mathbf{1 1}$. This is consistent with the reported bridged complex $\left[(\mathrm{AuCl})_{2}\right.$ (dnpype)] vs the bis-chelated complex [Au(dnpype) $\left.)_{2}\right] \mathrm{Cl}$.[29]

The ${ }^{31} \mathrm{P}$ NMR spectra of the bridged di-gold(I) (8a) and bis-chelated gold(I) (10a) in deuterated chloroform showed signals around $\delta 32.4,33.2$ and 15.1, 15.5 ppm, respectively (Table 1). The observed trend in ${ }^{31} \mathrm{P}$ NMR spectra of $\mathbf{8} \mathbf{a}$ and $\mathbf{1 0 a}$, where the chemical shift of $\mathbf{8} \mathbf{a}$ is deshielded to a greater extent than that of $\mathbf{1 0 a}$, is consistent with that observed for the dppe analogues, [(AuCl) $\left.{ }_{2}(\mathrm{dppe})\right]$ and $\left[\mathrm{Au}(\mathrm{dppe})_{2}\right] \mathrm{Cl}$.[1,16,17] The ${ }^{31} \mathrm{P}$ NMR spectrum in DMSO of $\mathbf{9}$ and $\mathbf{1 1}$ showed signals at $\delta 31.5$ and 22.3, respectively. This is also consistent with the observations made for complexes $\left[(\mathrm{AuCl})_{2}(\mathrm{dppe})\right]$ and $\left[\mathrm{Au}(\mathrm{dppe})_{2}\right] \mathrm{Cl}$. However, the reported ${ }^{31} \mathrm{P}\left\{{ }^{1} \mathrm{H}\right\}$ resonance of the analogous complex $\left[(\mathrm{AuCl})_{2}(\mathrm{dppey})\right]$, is at $12.8 \mathrm{ppm}$ (Table 1). [1]

The ${ }^{31} P\left\{{ }^{1} \mathrm{H}\right\}$ NMR spectra of the bridged complex $\mathbf{8} \mathbf{b}$ and bis-chelated complex $\mathbf{1 0 b}$ showed a doublet at $\delta 9.5 \mathrm{ppm}$ $\left[J_{A g-P}=225 \mathrm{~Hz}\right]$ and $\delta-2.1 \mathrm{ppm}\left[J_{A g-P}=240 \mathrm{~Hz}\right]$, respectively.
A similar bridged silver complex $\left[\left(\mathrm{Ag}_{2} \mathrm{O}_{4} \mathrm{C}_{12} \mathrm{H}_{6}\right.\right.$ (dppe) $]$ with a carboxylic group bridging two silver atoms, showed a coupling constant of $J_{A g-p}=230 \mathrm{~Hz}$ in $\mathrm{CDCl}_{3}$.[18] A coupling constant for the bis-chelated complex $\left[\mathrm{Ag}(\mathrm{dppe})_{2}\right] \mathrm{NO}_{3}$ with the value of $J_{A g-p}=231 / 266 \mathrm{~Hz}$ had been reported.[30]

Due to the hygroscopic nature of the compounds accurate elemental analyses could not be performed. Degrees of deviation were overcome by accounting for the presence of co-crystallised solvent in the crystal lattice, which were not removed after extended periods under high vacuum. This has been previously observed with a similar series of compounds within our research group,[33] where structures were confirmed by $x$-ray diffraction.

\section{Conclusions}

This paper reports the successful preparation of two alkyl, aryl-substituted bis-phosphines ligands, differing only in the composition of their backbone, and their subsequent complexation with gold and silver.

Two synthetic approaches were investigated in order to obtain the desired ligands. The first method involved the synthesis of butyldiphenylphosphine from triphenylphosphine (7), and thereafter the desired ligand was obtained via a lithium butylphenylphosphide intermediate. The second method involved the synthesis directly from bis-phosphines, dppe (1) and dppey (2).

The synthesis of two-coordinate (bridged) and four coordinate (bis-chelate) novel gold(I) complexes $\mathbf{8 a}, \mathbf{9}$ and $\mathbf{1 0 a}, \mathbf{1 1}$, and silver $(I)$ complexes $\mathbf{8 b}$ and $\mathbf{1 0 b}$ has been achieved. All of the synthesised complexes compared favourably to analogues reported in literature.

\section{Acknowledgements}

The authors would like to thank Project AuTEK (Mintek and Harmony Gold) for permission to publish this paper and for financial support. Further thanks go to University of the Witwatersrand for use of their facilities. 


\section{About the Authors}

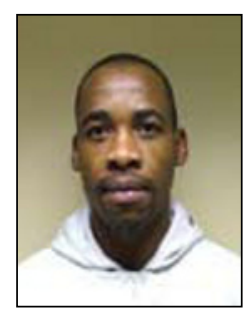

\section{Mr. David Khanye}

David Khanye is currently a first year PhD student at the University of Cape Town working on gold complexation of thiosemicarbazones and isothiazoles under supervision of Prof. Kelly Chibale, Dr. Judy Caddy and Dr. Greg Smith.

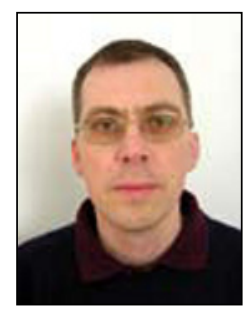

\section{Dr. Marcus Layh}

Dr. Marcus Layh is currently a research associate at the University of Münster and has held previous industrial and academic positions in Germany, the UK and South Africa. His research interests are in the field of main group organometallic chemistry.

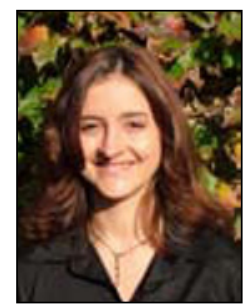

\section{Dr. Judy Caddy}

Judy joined Mintek in 2003 after obtaining her PhD in Organic Chemistry at the University of Johannesburg (Rand Afrikaans University). She began her research career looking at the synthesis and biological activity of a variety of phosphine compounds in a secondment to University of Witwatersrand. During this time Judy undertook a research visit to Heidelberg, Germany, where she investigated the gold labelling of neurologically active pentapeptides. Shortly after her return to South Africa she began heading up the AuTEK Biomedical Programme, along with taking on an honorary position at the University of Witwatersrand. Over the past three years Judy has actively supervised and co-supervised student projects at collaborating universities, along with her research activities at Mintek, where she is now involved in the development of therapies for cancer, HIV and malaria.

\section{References}

1 S.J. Berners-Price, PJ. Sadler, Inorg. Chem., 1986, 25, 3822 - 3827

2 B.R. Kimpton, W. McFarlane, A.S. Muir, P.G. Patel, J.L. Bookham, Polyhedron, 1993, 12, 2525 - 2534

3 Comprehensive Coordination Chemistry II, Vol. 1, Editors, J.A. McCleverty, T.J. Meyer, $1^{\text {st }}$ Ed. 2004, Pergamon, Elsevier, Ltd, London

4 T.S. Chou, Chung-Huang Tsao, Su Chun Hung, J. Org. Chem., 1985, 50, $4329-4332$

5 A. Bollman, K. Blann, J.T. Dixon, F.M. Hess, E. Killian, H. Maumela, D.S. McGuinness, D.H. Morgan, A. Neveling, S. Otto, M. Overett, A.M.Z. Slawin, P. Wasserscheid, S. Kuhlmann, J. Am. Chem. Soc., 2004, 126, $14712-14713$

6 J.S. Lewis, S.L. Heath, A.K. Powell, J. Zweit, P.. Blower, J. Chem. Soc., Dalton. Trans., 1997, 855 - 861
7 R.H. Crabtree, J. Organomet. Chem., 2005, 690, 5451-5457

8 M.J. McKeage, S.J. Berners-Price, P. Galettis, R.J. Bowen, W. Bouwer, L. Ding, L. Zhuang, B.C. Baguley, Cancer Chemother. Pharmacol., 2000, $46,343-350$

9 P. Le Floch, Coord. Chem. Rev., 2006, 250, 627-681

10 M.S. Balakrishna, R.M. Abhyankar, J.T. Mague, J. Chem Soc., Dalton Trans., 1999, 1407-1412

11 N. Mézailles, L. Ricard, F. Mathey, P. Le Floch, Eur. J. Inorg. Chem., 1999, 2233-2241

12 G.A. Bowmaker, J.P. Williams, Aust. J. Chem., 1994, 47, 451-460

13 S.J. Berners-Price, R.J. Bowen, P. Galettis, P.C. Healy, M.J. McKeage, Coord. Chem. Rev., 1999, 185 - 186, 823-836

14 R.J. Bowen, A. C. Garner, S.J. Berners-Price, I.D. Jenkins, R.E. Sue, J. Organomet. Chem., 1998, 554, 181-184

15 F. Mainza, F. Spindler, M. Thommen, B. Pugin, C. Malan, A. Mezzetti, J. Org. Chem., 2002, 67, $5239-5249$

16 S.J. Berners-Price, R.J. Bowen, M.A. Fernandes, M. Layh, WJ. Lesueur, S. Mahepal, M.M. Mtotywa, R.E. Sue, C.E.J. van Rensburg, Inorg. Chim. Acta, 2005, 358, 4237- 4246

17 S.J. Berners-Price, M.A. Mazid, P.J. Sadler, J. Chem. Soc., Dalton Trans., 1984, $969-974$

18 A.F.M.J. van der Ploeg, G. van Koten, A.L. Spek, Inorg. Chem., 1979, 18, $1052-1060$.

19 A.F.M.J. van der Ploeg, G. van Koten, Inorg. Chim. Acta, 1981, 51, 225-239

20 R.J. Bowen, J. Caddy, M.A. Fernandes, M. Layh, M. Mamo, R. Meijboom, J. Organomet. Chem., 2006, 691, 717-725

21 R.J. Bowen, M.A. Fernandes, P.W. Gitari, M. Layh, R.M. Moutloali, Eur. J. Inorg. Chem., 2005, 1955-1963

22 R.J. Bowen, D. Camp, Effendy, P.C. Healy, B.W. Skelton, A.H. White, Aust. J. Chem., 1994, 47, 693 -701

23 N.K. Roberts, S.B. Wild, J. Am. Chem. Soc., 1979, 101, 6254-6260

24 J. Dogan, J.B. Schulte, G.F. Swiegers, S.B. Wild, J. Org. Chem., 2000, 65 , 951- 957

25 R.S. Dickson, P. S. Elmes, W.R. Jackson, Organometallics, 1999, 18, 2912-2914

26 A.L. Airey, G.F. Swieger, A.C. Willis, S.B. Wild, Inorg. Chem., 1997, 36, 1588-1597

27 P. Brooks, M.J. Gallagher, A. Sarroff, Aust. J. Chem., 1987, 40, 1341-1351

28 A.M. Aguiar, D. Daigle, J. Am. Chem. Soc., 1964, 86, 2299 - 2300

29 S.J. Berners-Price, R.J. Bowen, T.W. Hambley, P.C. Healy, J. Chem. Soc., Dalton Trans., 1999, 1337-1346

30 S.J. Berners-Price, C. Brevard, A. Pagelot, P.J. Sadler, Inorg. Chem., 1985, $24,4278-4281$

31 S.J. Berners-Price, R. Bowen, P.. Harvey, P.C. Healy, G.A.. Koutsantonis, J. Chem. Soc., Dalton Trans., 1998, 1743-1750

32 P. Comba, C. Katsichtis, B. Nuber, H. Pritzkow, Eur. J. Inorg. Chem., 1999, $777-783$

33 F.H. Kriel "Gold(I) Phosphine Complexes as Selective Anti-Tumour Agents: Studies centred around the use of a dialkyl-hydrazine backbone", PhD Thesis, University of Witwatersrand, School of Chemistry, to be submitted January 2007 